\title{
BUILT HERITAGE DOCUMENTATION AND MANAGEMENT: AN INTEGRATED CONSERVATION APPROACH IN BAGAN
}

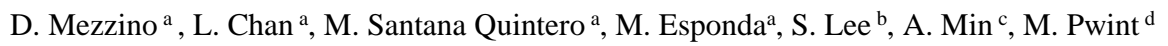 \\ ${ }^{\text {a }}$ Carleton Immersive Media Studio (CIMS), 1125 Colonel by drive, Ottawa, On, K1S 5B6 Canada, davide.mezzino@gmail.com, \\ lori.qk.chan@gmail.com, Mario.santana@carleton.ca, mariana_esponda@carleton.ca \\ ${ }^{\mathrm{b}}$ Cyark Foundation, 2201 Broadway Suite 602, Oakland, CA, 94612 USA, scott.lee@ cyark.org \\ ${ }^{\mathrm{c}}$ Department of Archaeology National Museum and Library (DoA)komindelhi06@ gmail.com \\ dYangon Technological University, p.mapwint@gmail.com
}

Commission II, WG VI/4

KEY WORDS: Risk Preparedness, Bagan, Built Heritage, Capacity-Building, Digital Workflows.

\begin{abstract}
:
Good practices in heritage conservation are based on accurate information about conditions, materials, and transformation of built heritage sites. Therefore, heritage site documentation and its analysis are essential parts for their conservation. In addition, the devastating effects of recent catastrophic events in different geographical areas have highly affected cultural heritage places. Such areas include and are not limited to South Europe, South East Asia, and Central America. Within this framework, appropriate acquisition of information can effectively provide tools for the decision-making process and management. Heritage documentation is growing in innovation, providing dynamic opportunities for effectively responding to the alarming rate of destruction by natural events, conflicts, and negligence. In line with these considerations, a multidisciplinary team - including students and faculty members from Carleton University and Yangon Technological University, as well as staff from the Department of Archaeology, National Museum and Library (DoA) and professionals from the CyArk foundation - developed a coordinated strategy to document four temples in the site of Bagan (Myanmar). On-field work included capacity-building activities to train local emerging professionals in the heritage field (graduate and undergraduate students from the Yangon Technological University) and to increase the technical knowledge of the local DoA staff in the digital documentation field. Due to the short time of the on-field activity and the need to record several monuments, a variety of documentation techniques, including image and non-image based ones, were used. Afterwards, the information acquired during the fieldwork was processed to develop a solid base for the conservation and monitoring of the four documented temples. The relevance of developing this kind of documentation in Bagan is related to the vulnerability of the site, often affected by natural seismic events and flooding, as well as the lack of maintenance. Bagan provided an excellent case study to test the effectiveness of the proposed approach, to prevent and manage the damages of catastrophic events, and to support retrofitting actions. In order to test the flexibility of adopted methodology and workflow, temples with different features - in terms of architectural design, shape, and geometry - were selected. The goals of these documentation activities range from testing digital documentation workflows for the metric and visual recording of the site (reviewing strengths and limitations of particular recording techniques), to the definition of effective conditions assessment strategies.
\end{abstract}

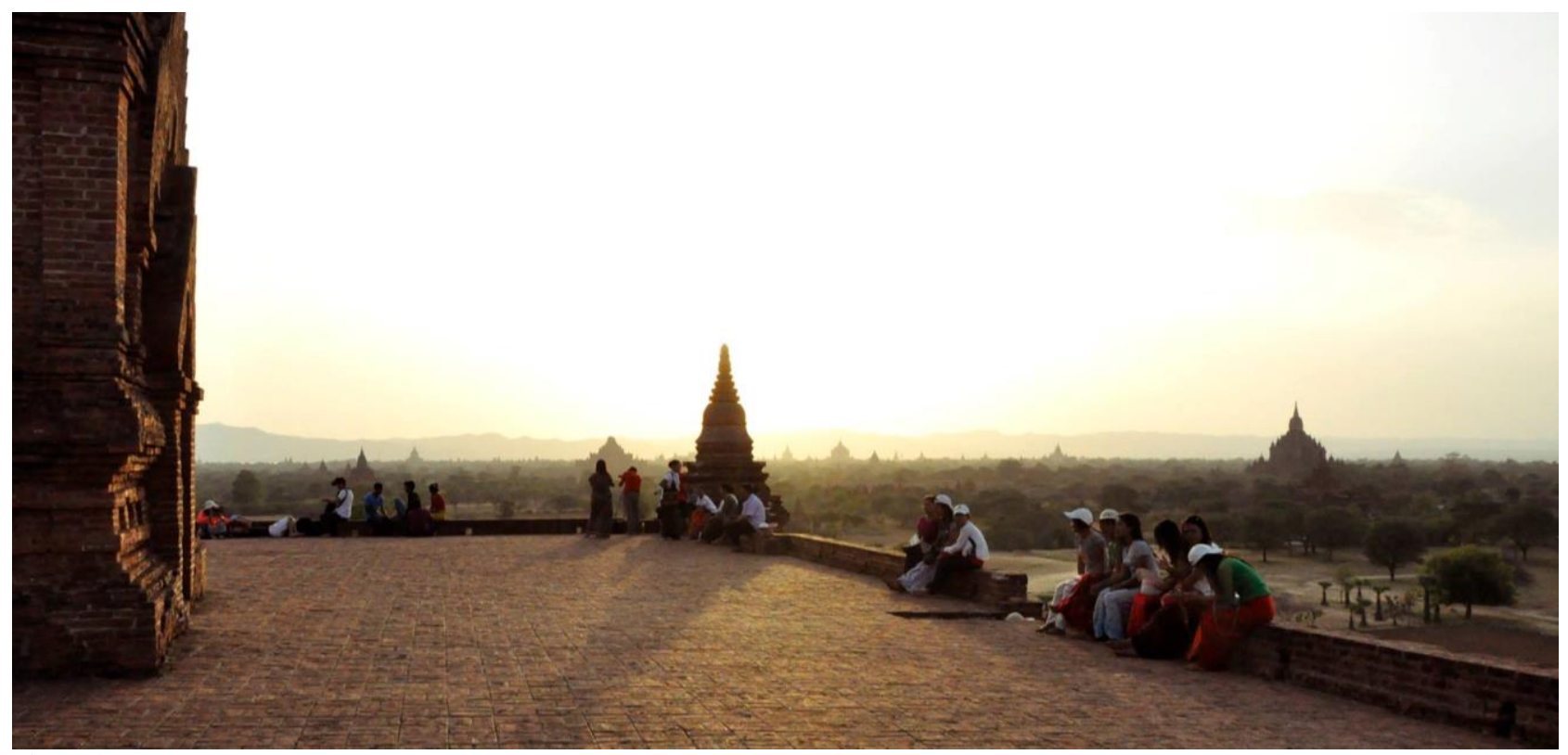

Figure 1 The plain of Bagan, Myanmar. Image source: Lori Chan. 


\section{INTRODUCTION}

Digital workflows in built heritage conservation are becoming exponentially employed to document, visualize, and manage built heritage assets. Due to the imminent risks from inherent and external causes of heritage sites, the documentation of valuable historic building or monuments has turned into a relevant priority.

Effective workflows are following described to collect, process, manage, and share heritage information. The adopted workflows aim to support the maintenance and conservation of heritage sites for future generations.

Past generations were only provided with basic tools like the film camera, and documentation was taken solely by manual means. With the rapid pace of technological innovation, the heritage documentation field has been revolutionized. New digital workflows for the documentation of Bagan built heritage have been employed to test the appearance of new documentation technologies.

Some of these tools include 3D scanning, drone photography, and virtual reality.

Aware of this considerations, this paper presents the documentation workflow of four selected temples in Bagan, Myanmar, stressing:

- The role of visual information for Bagan's built heritage conservation and management, aware of the national and international standards;

- Conservation challenges of Bagan's built heritage that will consider its nomination in the World Heritage List (WHL);

- strengths and limitations of IT supported recording techniques;

- An analysis of character defining elements that attribute value to Bagan's historical structures;

- Criteria and techniques to conduct a condition assessment of Bagan's built heritage;

- The importance of accurate records and proper step-by-step documentation that will lead to effective decision-making for the management of heritage properties;

- The effectiveness of multidisciplinary collaborations and capacity-building activities to increase awareness and engagement towards built heritage;

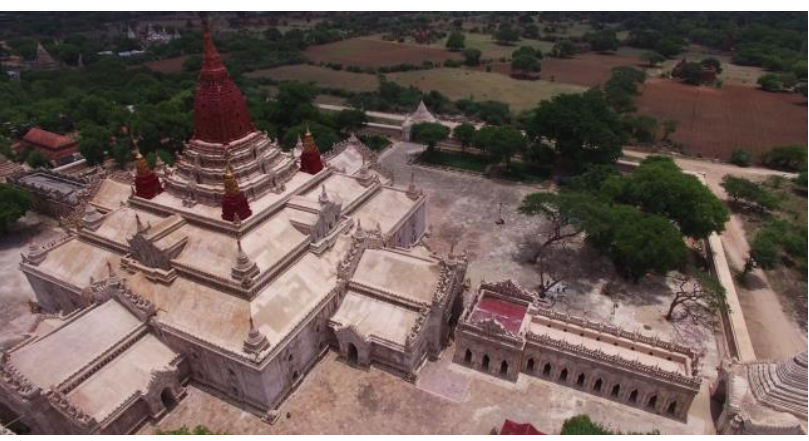

Figure 2 Ananda-gu-hpaya-gyi temple, Bagan. Photo taken with a drone DJI Inspire 1. Image Source: Scott Lee.

The collaboration with intergovernmental organizations, private foundations, governments, and consulting companies, has provided the adequate knowledge and experience for the following contribution.

The employment of digital documentation workflows and capacity-building strategies are presented using Bagan as a case study. Most of the tools employed in the on-field recording activities are freely and Commercially available Off-The-Shelf (COTS) made applications.

Finally, limits (increasing threats and fragmentation of data), challenges in heritage documentation, as well as new perspectives (given by the increasing pace of innovation) are discussed in detail in a method that considers the international framework.

\subsection{Territorial framework, historical and socio-cultural context of Bagan}

The site of Bagan (Figure 1) is located in the centre of Myanmar in the south east Asia (Figure 3). It is one of the most interesting and ancient Asian heritage sites with over three thousand monuments.

Bagan is one of Asia's most important centres of Theravada Buddhism. Its area measures approximately $91 \mathrm{~km}^{2}$ (Stander, 2013). According to [Pichard, 1992], the area of Bagan (or "Pagan" as it was also called) includes three main areas: the lively town of Nyaung $U$, the historic walled city of Old Bagan and further on the south the New Bagan (Bagan Myothit). From the natural point of view, the area is featured by the Ayeyarwaddy River that crosses all Myanmar flowing into the Andaman Sea. The river is and has always been Myanmar's vital artery. Further, the raw materials of Bagan buildings' constructive elements such as bricks and mortar are directly connected to the river.

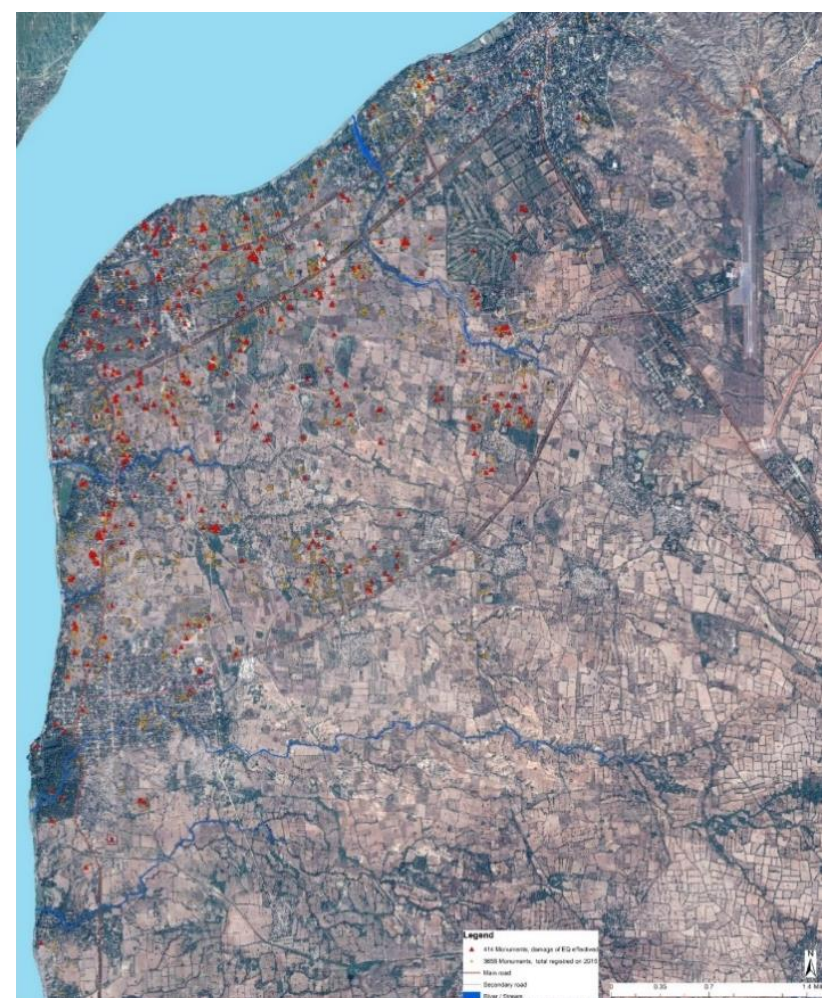

Figure 3 Map of Bagan, Myanmar. The map includes the three main areas of Bagan: the lively town of Nyaung U, the historic walled city of Old Bagan and further on the south the New Bagan (Bagan Myothit).

The legendary origin of Bagan dates back to the II century, but its major building development only began after the ascension of King Anawratha (eleventh century). This pattern of construction continued throughout the sixteenth and twentieth centuries as reported by some mural paintings. Bagan's site counts more than three thousand monuments even if documentary sources report 
that in the past, between eleventh and thirteenth centuries, there were more than 13,000 stupas (see paragraph 1.2) and temples.

Many of the temples are still being venerated by the local population as well as by national and international pilgrims. Most of the about 3000 recorded Buddhist monuments ranging from small stupas and temples to monastic complexes and several enormous stucco-covered structures were built during the eleventh to the thirteen centuries - when Bagan was flourishing as the capital of the first Myanmar kingdom. Even if constructions slowed down after the thirteen and fourteen century (due to several historic and circumstances such as the Mongol invasions and the capital shift from Bagan to Mandalay), albeit at a slower pace, Bagan's development still continued (Stander, 2013).

In the past years, contemporary to a failed attempt of nominating Bagan for the World Heritage List in the 1990s, Myanmar's military government directed an extensive reconstruction programme of religious monuments in Bagan. Between 1995 and 2012, more than 1000 pagodas and temples were reconstructed and about 600 were partially rebuilt.

International media and international expert communities have repeatedly scolded the Myanmar government for their anachronistic construction and unprofessional reconstruction work at the historic site. However, the military government's objective when publicly campaigning for the reconstruction of Bagan was most likely not first and foremost for the compliance with international conservation standards, but rather for pursuing political power ambitions by appropriating a historic site of national importance (Mezzino \& Santana Quintero, 2016).

\subsection{Bagan Cultural Built Heritage}

Bagan built heritage consists of both secular and religious architecture. Consequently, the site has a complex variety of architectural types including monasteries, underground structures, royal palaces (mostly ruined), local housing (for different social classes), stupas, and temples.

Religious architectures in Bagan include three main typologies: stupas, temples and monasteries. Monasteries usually use wood as its building material, while stupas and temples are masonry structures of clay bricks.

The main difference between stupas and temples concerns the use of the building. Indeed, the stupa is a monumental structure to commemorate the Buddha or his memorable deeds (Pichard, 1992). Stupas may have a variety of contours; nevertheless, bellshaped stupas are most common for the larger stupas as they received patronage from King Anniruddha during the country's unification (Wales, 1973)

\subsubsection{Bagan Temples}

Temples in Bagan were built as places of worship and devotion, completely accessible to the public and often contained relics and sacred objects. In terms of plan disposal there are two main typologies. The first one is based on a solid brick core "encircled by vaulted corridor" (Stander, 2013, p.62) The second kind of ground plan instead has an open vaulted shrine most of the time surrounded by a vaulted corridor (Stander, 2013). Apart from these two main typologies, it is possible to find other creative solutions such as temples with cruciform ground plan or pentagonal plan.

From the decorative point of view, entrance halls and corridors were usually decorated with wall paintings (Figure 4). Some temple interiors were fully ornamented with murals, including the interior dome, as religious devotion to the Buddha.

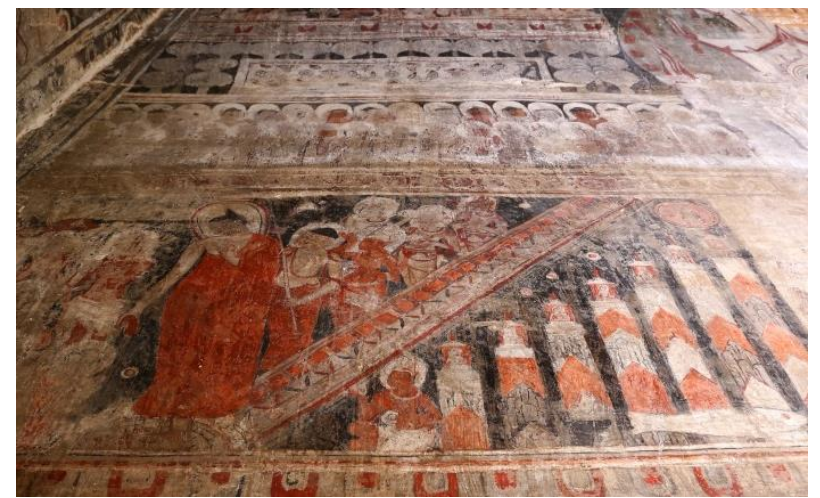

Figure 4. Example of interior mural painting, Loka-hteik-pan. Source: Davide Mezzino.

The main purpose of these artworks was most likely educational. Books were extremely expensive and wall painting decoration was an efficient way to disseminate Buddhist stories for increasing people's awareness (Thanegi, 2005). Most of the temples present also, both in the interior and exterior, large areas of plain wall surfaces with juxtaposed stucco ornament. Furthermore, many temples feature decorations in glazed ceramic mainly employed to decorate the high base mouldings. These decorations, usually formed in plaques, were made of silica, white clay, calcium, lead oxide, copper oxide, chrome oxide, vanadium oxide and feldspar (Thanegi, 2005, p.53). 


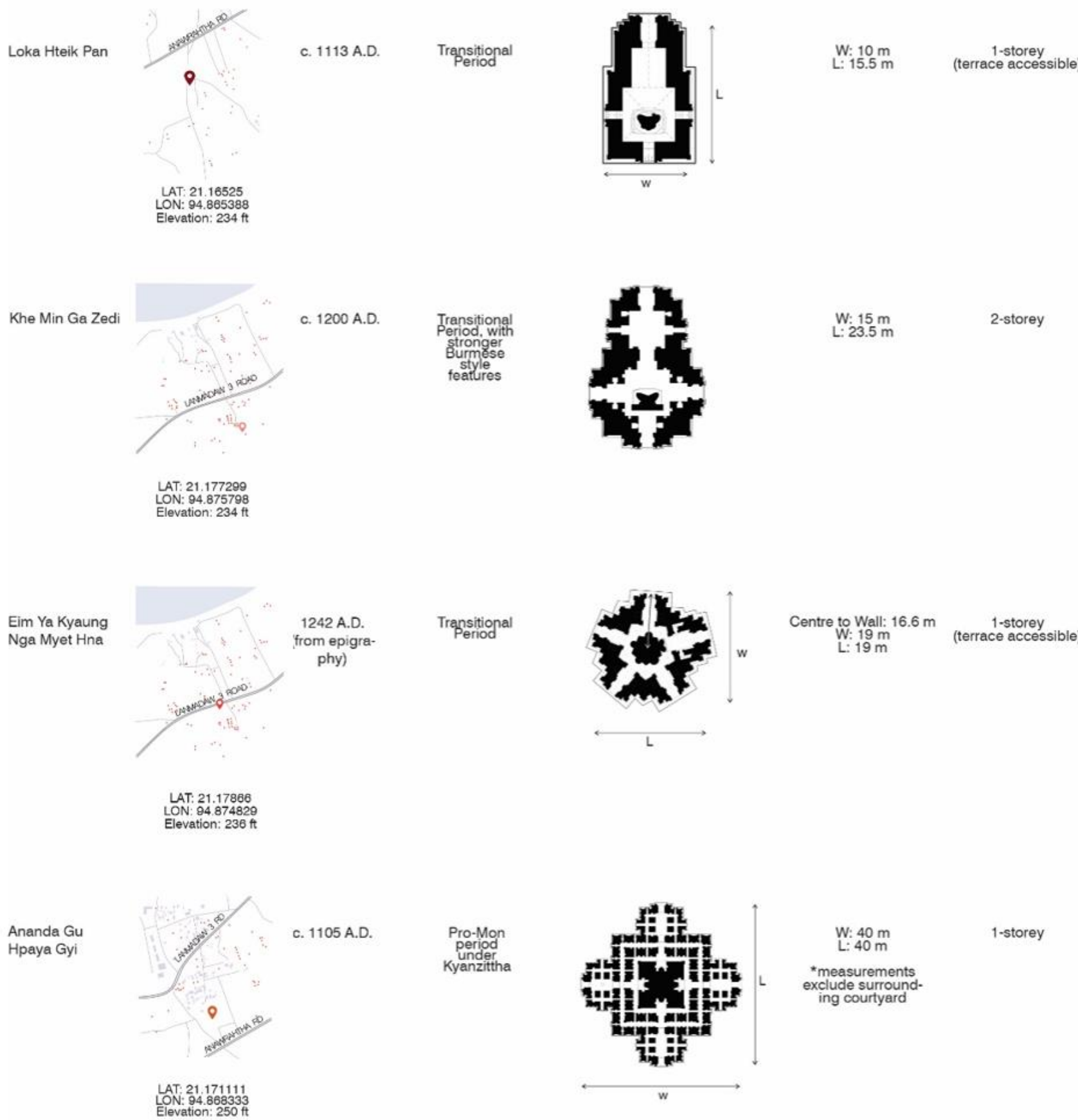

Figure 5. Digital Data archive of the four temples with contextual information. Compiled by Davide Mezzino and Lori Chan.

\section{CAPACITY-BUILDING FOR BAGAN BUILT HERITAGE RECORDING}

The capacity-building digital documentation workshop included 13 graduate and undergraduate students and Professors of Carleton University, 48 graduate and undergraduate students and Professors of the Yangon Technological University, staff of the DOA, and four experts from the CyArk Foundation that provided most of the financial and technical support to the mission. In order to make the workflow more efficient, the participants were divided into 6 different teams respectively dealing with: aerial and terrestrial photogrammetry as well as panoramic photos, laser scanning, electronic distance measurements (Total Station survey), hand measurements, character defining elements analysis, and condition assessment.

The selected four temples were different in terms of shape, dimensions, design, decorative apparatus, construction period, location and orientation (Figure 5). They included temples: Lokahteik-pan, Khe-min-ga-zedi, Eim-ya-Kyaung-nga-myet-hna and Ananda-gu-hpaya-gyi temple (Figure 2). 


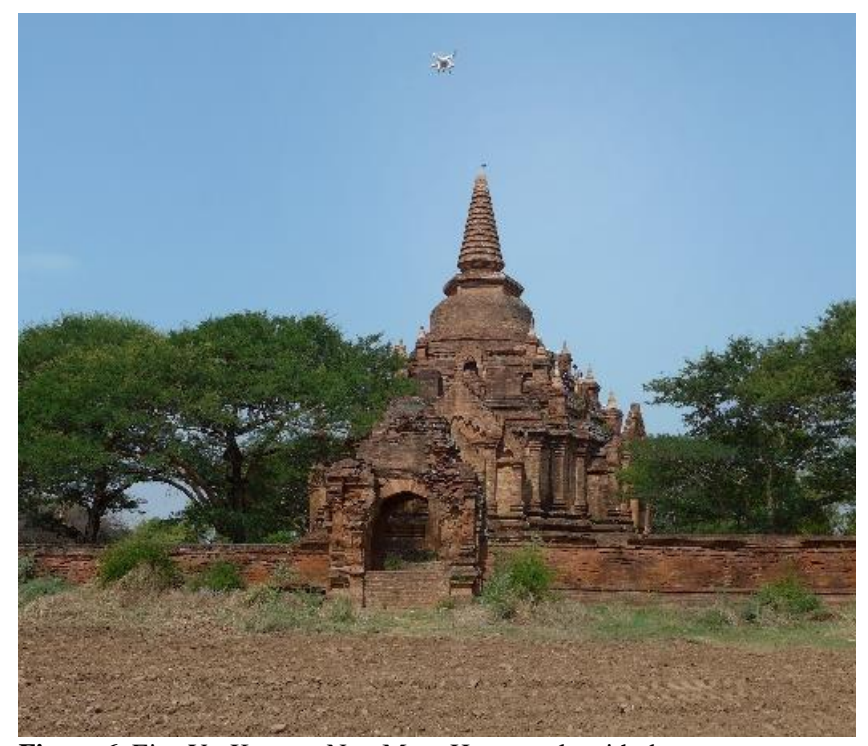

Figure 6 Eim-Ya-Kyaung-Nga-Myet-Hna temple with drone

These temples were chosen to define a flexible methodology that could be applied to the heterogeneous Bagan monuments.

\subsection{Documentation components}

The defined documentation components to be elaborated for the conservation of the four recorded structures included:

- the temple and sites' building characterization, including character defining elements analysis and values assessment;

- a condition assessment (Figure 8);

- a set of interviews with local actors concerning value of the site and the ongoing conservation actions;

- field notes and sketches (Figure 7);

- measured drawings (site plans, floor plans, cross sections and elevations);

- consolidated point cloud models;

- a digital photographic portfolio;

- panoramic photos;

- a final report describing the documentation strategy and results;

- guidelines and protocols.

- The measured drawings have been elaborated in scale $1: 200,1: 100$ and $1: 50$.

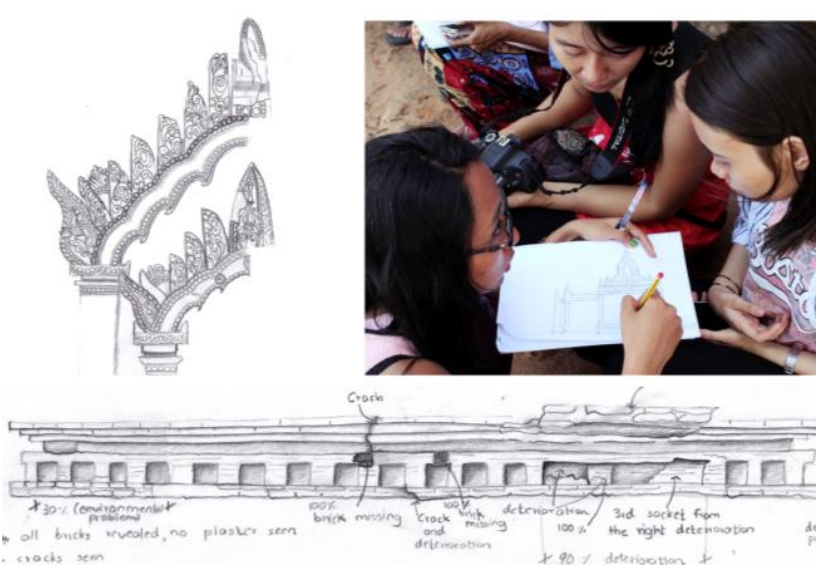

Figure 7 Examples of the field notes and sketches developed in the site.

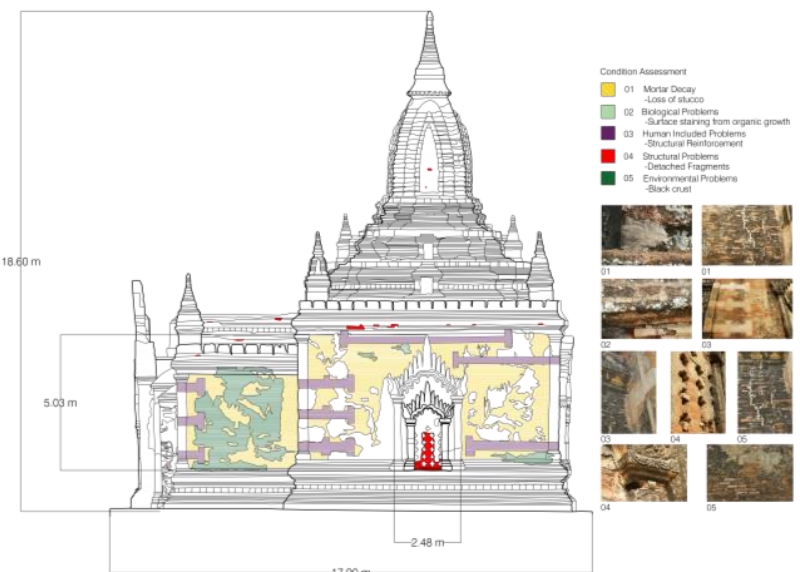

Figure 8 Example of the developed condition assessment on the West façade of the Loka-hteik-pan temple. Image source: Davide Mezzino.

\section{DIGITAL WORKFLOWS: RECORDING} STRATEGIES AND DATA PROCESSING SOLUTIONS

Considering the context of Bagan, the adopted documentation strategy consisted of the main following steps:

1. Define site information keeper;

2. Form 6 Teams (for each team elect Team Leader);

3. Employ photogrammetric technique to gather qualitative as well quantitative information of the four recorded temples;

4. Adopt laser scanner techniques to obtain a higher level of detail of the recorded temples;

5. Panoramic photography to capture the comprehensive conditions of the site during the recording activity; (Figure 9)

6. Make topometric measurements with total station to reference and combine the information coming from the laser scanning and photogrammetric survey;

7. Hand measurements have also been included in the workflow in order to present a cost effective technique;

8. Character defining elements analysis and condition assessment have been developed dividing the exterior and the interior of the temples into small sections in order to be able to gain accurate information. In this phase, field notes and digital photography supported the both character defining elements analysis and condition assessment.

The mentioned techniques have been employed for recording the exterior and interior of the four temples. During the survey phase, due to the inadequate lighting conditions inside the temples, artificial lighting systems were used to increase illumination.

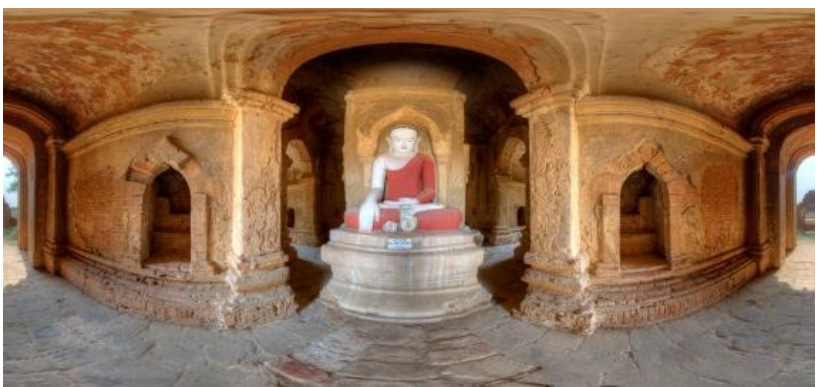

Figure 9: Panoramic Interior of temple Eim-Ya-Kyaung-Nga-Myet-Hna, East Entrance. Image source: Mario Santana Quintero. 


\subsection{On-site recording tools}

The documentation of the four temples has been carried out employing different techniques: Electronic Distance Measurement (EDM), terrestrial and aerial photogrammetry, Laser Scanning, Record Photography and Hand Measurements. The digital recording has been carried out with the support of several surveying instruments; more specifically:

- Leica Geosystems Total Station TS11 and a Leica Geosystems Total Station TS06 with a distance accuracy of $2 \mathrm{~mm}$ and angular $2 \mathrm{ppm}$ for linework;

- Nikon D800 DSLR camera with $36 \mathrm{MP}$

- tripods;

- Drone Phantom 2 Vision +; (Figure 6)

- DJI Inspire 1;

- Nodal Ninja adapter for aspherical images and fisheye Nikkor $10.5 \mathrm{~mm}$ lens;

- 2 Faro Laser Scanner Focus3D.

\subsection{Information processing strategy}

Information coming from aerial/terrestrial photogrammetry and laser scanning (point cloud) has been combined with Total Station data and hand measurements. The point clouds created from the different techniques have been combined in Autodesk Recap and Faro Scene 6.2 (Figure 10).
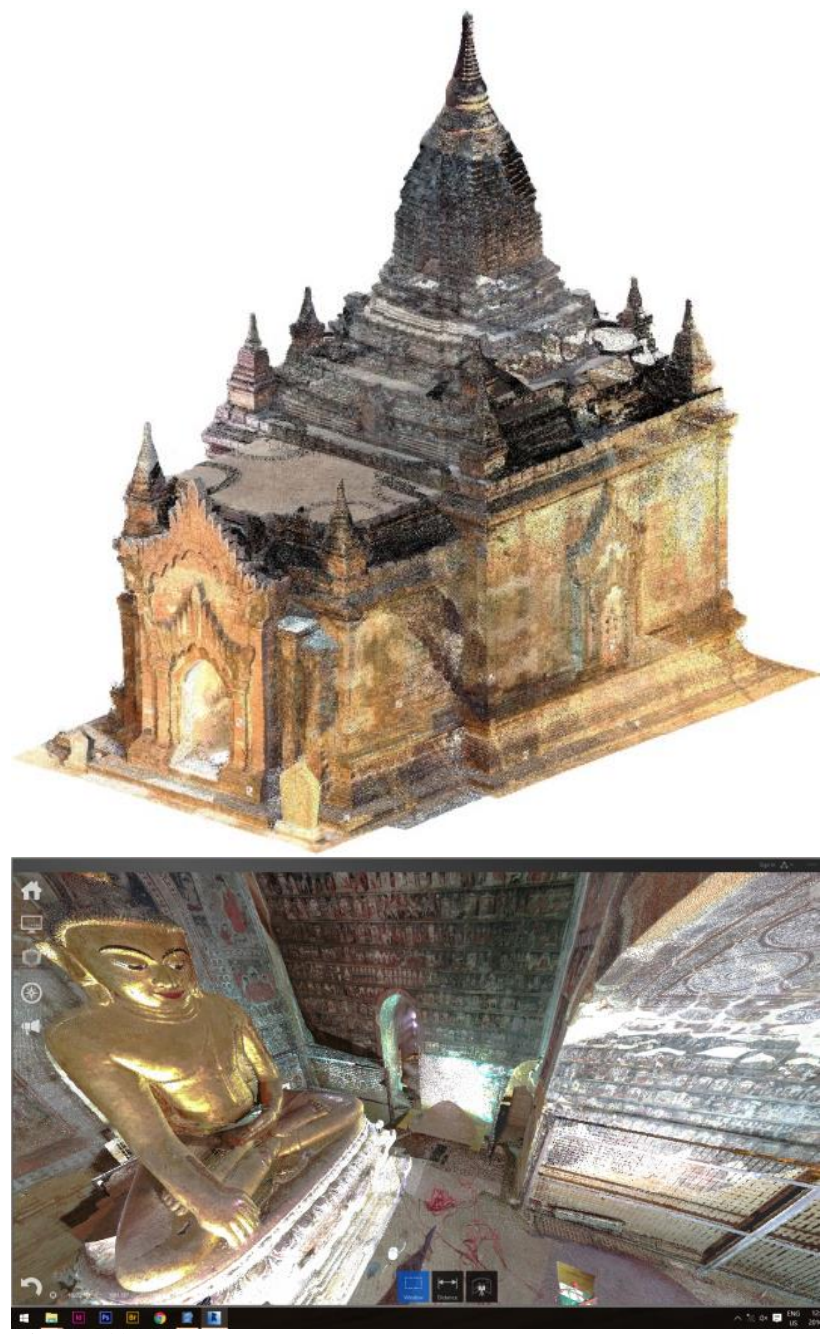

Figure 10. Pointcloud model of Loka-hteik-pan temple (exterior an interior views). Pointclouds coming from the different techniques (aerial and terrestrial photogrammetry and laser scanning) combined in Autodesk Recap.

Once all the data has been processed, the consolidated colorized point cloud models have been used to generate orthophotos (Figure 11). These are employed as graphical bases for the condition assessment and for the analysis of character defining elements.

To generate the orthophotos, the combined pointclouds in Autodesk Recap were exported as .pts files and imported into Geomagic Studio 2014. A new coordinate system was then defined to ensure a perfectly perpendicular view of each façade, and subsequently the facades were captured in high-resolution at a size of $10,000 \times 10,000$ pixels.

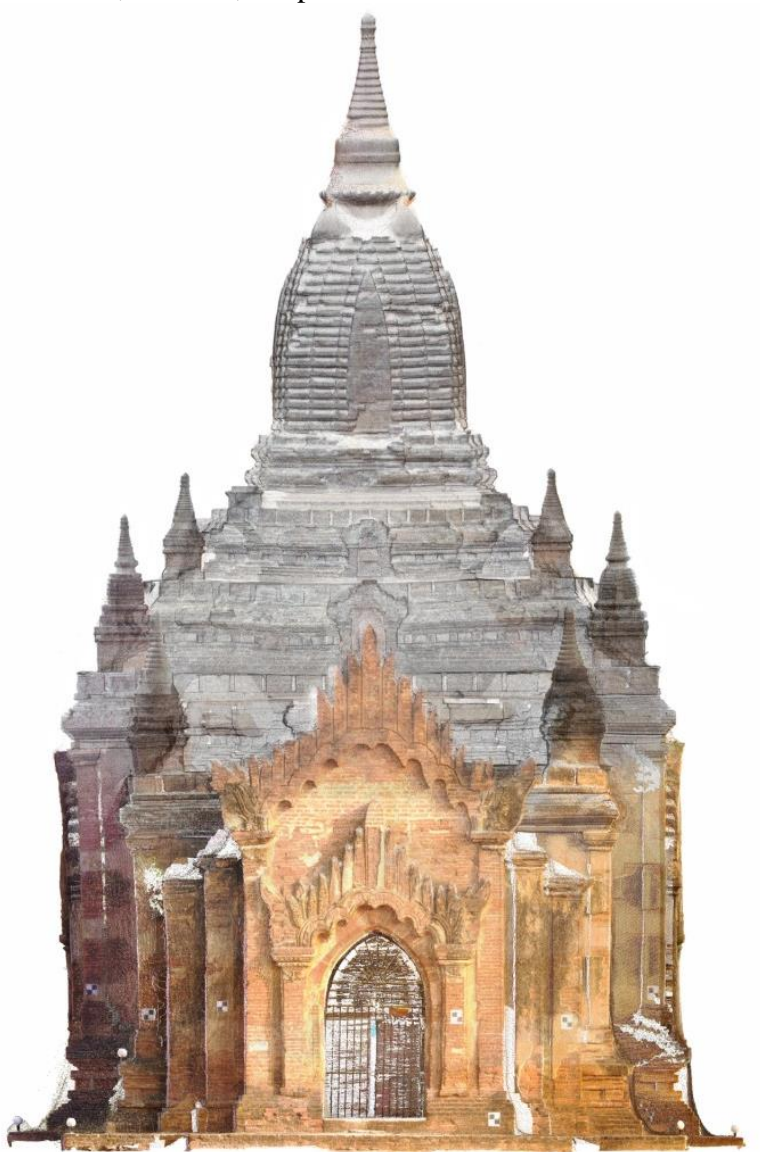

Figure 11: Orthographic projection of the North Façade of the LokaHteik-Pan temple generated from the pointcloud.

Two dimensional measured drawings have been developed from these orthophotos (Figure 12)'. These drawings were drawn at a scale of 1:50 and include enough detail to assess the condition and to analyse the physical structure of the temple. This approach was replicated for the successive drawings, including elevations, floorplans, cross sections, site plans and roof plans of the four recorded temples. 


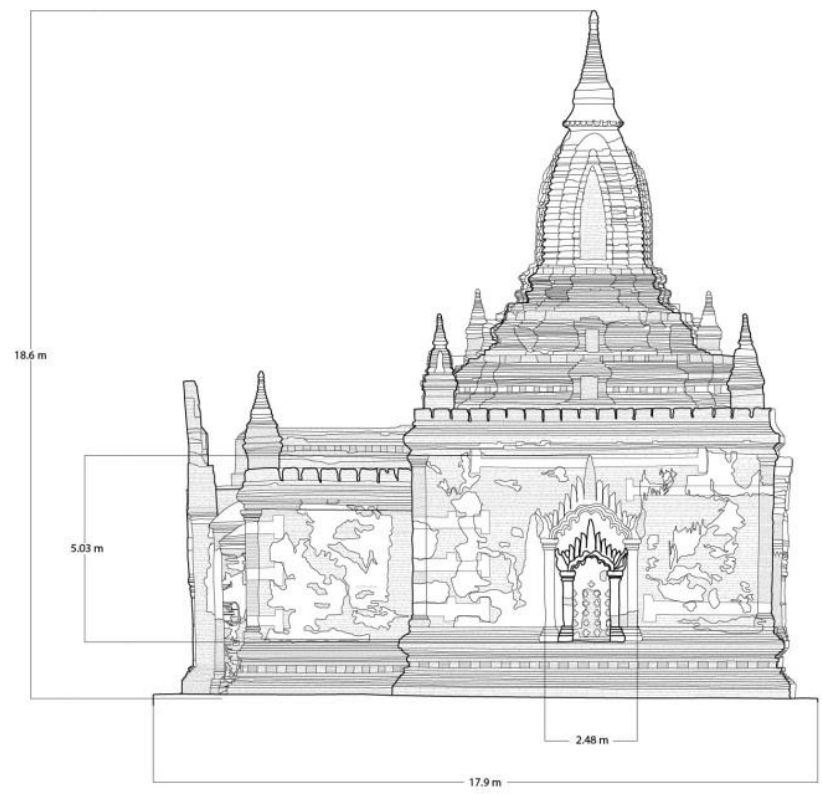

Figure 12: Drawing of West façade of Loka-Hteik Pan temple. Source: Authors.

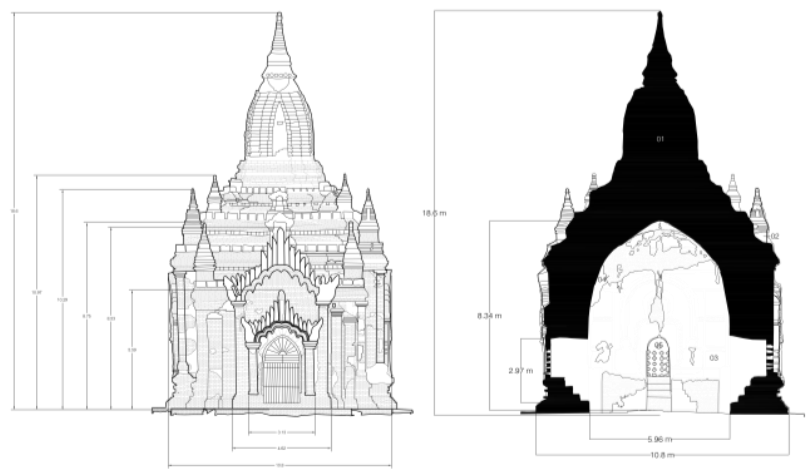

Figure 13: Drawing of the North façade and of the east-west cross section of Loka-Hteik Pan temple. Source: Authors.

\section{CONCLUSIONS}

The developed documentation project provides solid outputs for the goal of developing conservation strategies. Capacity-building activities, carried out during the data acquisition and data processing phase, are vital to training local and non-local future heritage professionals. These activities exposed practical conservation challenges and limitations or strengths of heritage recording tools.

The documentation also provided useful information about the stabilization of interventions. For instance, the integrated documentation developed for the four temples showed the intervention after the seismic event of 1975.

The condition assessment documents the performance and compatibility of previous interventions. This showed, for instance, the relationship between the reconstructed parts using cement mortar and steel reinforcement, and the original ones in brick masonry.

Further, these analyses can be used for the development of guidelines for the rehabilitation and risk preparedness of the documented temples. The adopted documentation workflow could then be extended the other historical Bagan structures.
In case of seismic events, the analysis of character defining elements (Figure 14) helps plan the salvaging and cleaning process of the damaged monuments. It defines which elements of temple or building structure should be prioritized to preserve its heritage value. This information supports the classification of the objects or elements identified and, in case of collapse, their reallocation by anastilosis (according to the principles of the Athens Charter,1931 and Venice Charter, 1964).
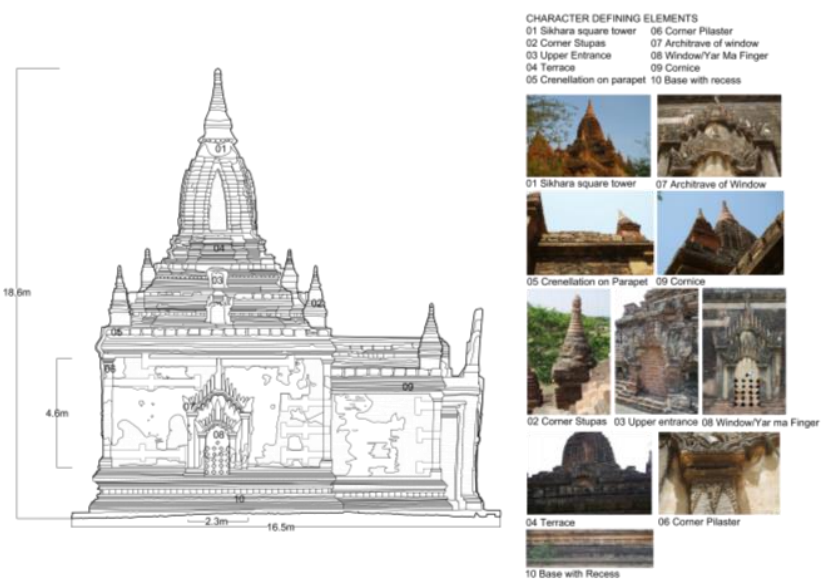

Figure 14: Example of the character defining element analysis of the West façade of the Loka Loka-Hteik Pan temple. Source: Davide Mezzino.

In addition to the character defining elements analysis and conditional assessment, measured drawings (Figure 13) and photographic documentation are fundamental to monitor the site and to orient management, planning and/or conservation actions.

Lastly, in the case of catastrophic events, this information is useful for the selection and careful storage of collapsed elements (bricks, artefacts, stones, stucco, plaster, etc.) as well as for future restoration.

\section{ACKNOWLEDGEMENTS}

The authors wish to acknowledge and thank the support of Myanmar's Department of Archaeology, National Museum and Library (DoA), the Association of Myanmar architects, and UNESCO for this unique opportunity to collaborate in the preservation of this important landmark. Special thanks also goes to the Yangon Technological students and professors and to the Carleton students that with their efforts and competences strongly supported this project. Finally, it is important to note that Cyark made our activity feasible, by providing funds, tools and expertise. In particular, a special thanks goes to Scott David Lee, Donn Anthony Fassero, Oliver Dusan Monson, and John Ristevski.

\section{REFERENCES}

Banfi F., 2016. Building Information Modelling - A Novel Parametric Modeling Approach Based on 3D Surveys of Historic Architecture. 6th International Conference, EuroMed 2016, Nicosia, Cyprus, October 31 - November 5, 2016, Proceedings, Part II. Digital Heritage. Progress in Cultural Heritage: Documentation, Preservation, and Protection, ISBN 978-3-31948495-2, pp. 116-127

Bedford, J. Papworth, H. ed. 'Measured and drawn: techniques and practice for the metric survey of historic buildings' English 
Heritage, Kemble Drive, Swindon (2009), http://www.englishheritage.org.uk/content/publications/ docs/measured-anddrawn.pdf (last accessed: May 15, 2015)

Bedford,J. Pearson, T. Thomason, B. Traversing the Past, English Heritage (2011), http://www.english-heritage. org.uk/content/publications/publicationsNew/guidelinesstandards/traversingthepast/Traversing_the_Past.pdf (last accessed: May 15, 2015)

English Heritage '3D Laser Scanning for Heritage: Advice and guidance to users on laser scanning in archaeology and architecture', (2009), http://www.englishheritage.org.uk/publications/3d-laser-scanning-heritage2/ (last accessed: May 15, 2015)

English Heritage 'Understanding Historic Buildings: A guide to good recording practice' (2006), http://www.englishheritage.org.uk/publications/understanding-historic-buildings/ (last accessed: May 15, 2015)

English Heritage 'The Presentation of Historic Buildings survey in CAD', http://www.english-heritage.org.uk/ publications/historic-building-survey-in-cad/ (last accessed: Dec 19, 2012)

Letellier, R. Schmid, W. LeBlanc, F. 'Guiding Principles Recording, Documentation, and Information Management for the Conservation of Heritage Places' The Getty Conservation Institute, J. Paul Getty Trust (2007), http://www.getty.edu/ conservation/publications_resources/pdf_publications/ recordim.html (last accessed: May 15, 2015)

Mezzino D., Santana Quintero M., Ma Pwintb P., Tin Htut Latt W., Rellensmann C., "Technical assistance for the conservation of built heritage at Bagan, Myanmar". In XXIII congress International Society for Photogrammetry and Remote Sensing, Prague, 12 July - 19 July, 2016.

Pichard, P. (1992). Inventory of monuments at Pagan. Paris: UNESCO.

Mezzino D., Santana Quintero M., "Capacity building for preparedness and risk management: an integrated approach for Bagan built heritage". In ICOMOS AGA\&amp;ADCOM, Scientific Symposium on "Post-Disaster Reconstruction", Istanbul, 15-21bOctober, 2016.

Mezzino D., Santana Quintero M., Pwintb P. Ma, Tin Htut Latt W.,. Rellensmann C., "Technical assistance for the conservation of built heritage at Bagan, Myanmar". In XXIII congress International Society for Photogrammetry and Remote Sensing, Prague, 12 July -19 July, 2016.

Mezzino, D., Pei C. W., Santana-Quintero M. (2016). Interpretation of Sensor-Based 3D Documentation. In Münster S., Pfarr-Harfst M., Kuroczyński P., Ioannides M. (Eds.), 3D Research Challenges in Cultural Heritage. Volume 2: How to manage data and knowledge related to interpretative digital $3 D$ reconstruction of Cultural Heritage? Berlin: Springer.

Mezzino, D., \& Rinaudo, F. (2015). GIS and 3D modeling for Cultural Heritage. In R. Tamborrino (Ed.), Telling the history of the city in the age of the ICT Revolution (pp. 143-153). Roma: Centro per lo studio di Roma (CROMA) - Università degli studi Roma Tre.
Pichard, P. (1992). Inventory of monuments at Pagan. Paris: UNESCO.

Pichard, P. (2013). Today's Pagan: Conservation under the Generals. In M. Falser \& M. Juneca (Eds.), 'Archaeologizing' Heritage? Transcultural Entanglements between Local Social Practices and Global Virtual Realities (pp. 235-249). Berlin: Springer-Verlag.

Stander, D. M. (2013). Ancient Pagan. Buddhist Plain of Merit. Bangkok: River Books.

Thanegi, M. (2005). Myanmar Architecture cities of gold. Singapore: Times Editions Marshall Cavedish.

Wales, G.Q. Horace. (1973). Early Burma Old Siam: A Comparative Commentary. London: Quaritch.

Weise, K. (2016). Bagan Earthquake Response - Implementation of Work-Plan Day 14. 